\title{
Investigating Problem Solving Skills and Chemistry Learning Experiences of Higher Education Base on Gender and Grade Level Differences
}

\author{
Dwi Wahyudiati ${ }^{*}$ \\ ${ }^{1}$ Mataram State Islamic University, West Nusa Tenggara, Indonesia
}

DOI: $\underline{10.29303 / \text { jossed.v2i2.632 }}$

\section{Article Info}

Received : February 17th, 2021

Revised : September 17th, 2021

Accepted: October $18^{\text {th }}, 2021$

\begin{abstract}
The purpose of this study was to investigate the problem-solving skills (PSS) and chemistry learning experiences (LE) of teacher candidates. 191 pre-service chemistry teacher (130 women, 61 men) were taken as the research sample using the purposive random sampling technique. The research design used a cross-sectional survey with focus group interviews. The quantitative data obtained were analyzed using the MANOVA test and while the interview data using the Patton analysis technique. The research findings show that: 1) the level of the chemistry learning experience of pre-service chemistry teacher (LE) is higher than the ability of problem-solving skills (PSS); 2) the level of ability of female chemistry teacher candidates for PSS and LE was found to be higher than that of males; (3) there are differences in PSS and LE based on grades levels, but there is no difference based on gender; 4) there is a difference in PSS and LE between freshman, sophomore, and junior grades. The findings of the interview are relevant to the results of the survey which proved that male and female students both have positive attitudes towards chemistry, however, it was found that there were differences in PSS and LE between grade level (1 ${ }^{\text {stgrade, }} 2^{\text {stgrade, }} 3^{\text {st }}$ grade). Thus, it is suggested that the learning process in universities prioritizes the development of LE and PSS in chemistry learning so as to improve the soft skills and academic achievement of prospective chemistry teachers.
\end{abstract}

Keywords: problem-solving skills; learning experiences; gender differences; grade level; Pre-Service Chemistry Teachers

Citation: Wahyudiati, D. (2021). Investigating Problem Solving Skills and Chemistry Learning Experiences of Higher Education Base on Gender and Grade Level Differences. Journal of Science and Science Education, 2(2), $62-67$. doi:https://doi.org/10.29303/jossed.v2i2.632

\section{Introduction}

Lecturers have a very important role in improving the quality of competency of chemistry teacher candidates. Referring to the 21st-century learning output, it is no longer focused on cognitive aspects, but rather prioritizes the development of soft skills of students so that they are able to compete and play an active role in facing the era of industrial revolution 4.0. The soft skills that prospective teachers must have include problem-solving skills, self-efficacy, critical thinking skills, collaboration, and communication skills, and scientific attitudes (Villafane et al., 2014; Ismiani et al., 2017; Cheung, 2011; Fadli \& Irwanto, 2020; Sumardi et al., 2020). Likewise, the quality of chemistry teacher candidates who are able to compete in the era of industrial revolution 4.0 is not only focused on academic achievement or cognitive learning outcomes but also the development of soft skills such as problem-solving skills and chemistry learning experiences (Cheung, 2011; Wahyudiati et al., 2020). However, the development of problem-solving skills and chemistry learning experiences in the learning process tends to be neglected so that it has an impact on the low problem-solving skills and learning 
experiences of prospective chemistry teachers (Taber, 2011; Wahyudiati et al., 2019).

Problem solving skills (PSS) are the abilities that individuals have in analyzing, identifying problems, formulating problems, compiling and testing hypotheses, and formulating conclusions (Osborne et al., 2003). In the learning process, the development of problem-solving skills (PSS) and student learning experiences greatly affect learning outcomes which include affective, cognitive, and psychomotor aspects of students (Wahyudiati et al., 2020; Osborne et al., 2003; Çalik et al., 2014). Thus, it is very important to develop problem-solving skills and increase the learning experience of prospective chemistry teachers so that it has a positive effect on academic achievement and future career success (Villafane et al., 2014; Irwanto et al., 2018b; Mataka \& Kowalske2015). This factual condition is contrary to the practice of learning in higher education which prioritizes the neatness of student cognitive learning outcomes compared to the development of problem-solving skills, chemistry learning experiences, and critical thinking skills of prospective chemistry teachers (Villafane et al., 2014; Çalik et al., 2014; Myers \& Fouts, 1992) so that it is very urgent to conduct research that examines problemsolving skills (PSS) and the learning experience of students in chemistry in higher education.

Learning experiences (LE) or learning experiences are indicators of scientific attitudes. A scientific attitude is an individual's ability to solve a problem systematically through the scientific method (Prabowo, 2015). In the application of the scientific method, problem-solving skills are needed to solve a problem so as to produce valid conclusions, especially in chemistry learning which consists of understanding concepts and proofing concepts through experimental activities. Thus the chemistry learning experience (LE) and problem-solving skills (PSS) possessed by students influence one another. This means that the higher the problem-solving skills that are owned will have an impact on improving the learning experience of students, and vice versa. However, research studies examining PSS and LE of chemistry teacher candidates are still limited and more focused on scientific attitudes and cognitive achievement (Çalik et al., 2014; Wahyudiati et al., 2020; Osborne et al., 2003). Moreover, measurement of the ability of PSS and LE of chemistry teacher candidates has not been carried out much, even measuring the two aspects simultaneously has never been done (Villafane et al., 2014; Wahyudiati, 2019; Fadli \& Irwanto, 2020; Mataka \& Kowalske, 2015).

The ability of PSS and LE for chemistry teacher candidates must be developed so that the learning objectives of chemistry can be achieved which include cognitive, affective, and psychomotor aspects.
However, based on empirical studies it proves that chemistry learning in Indonesian universities is more focused on mastering concepts rather than developing soft skills in both attitudes and skills (Wahyudiati, 2010; Nurlita, 2008; Irwanto et al., 2018b; Wahyudiati, 2016; Wiwit et al., 2013). Referring to the results of the empirical study, it reveals various problems in learning chemistry, including the application of monotonous learning models, methods and strategies, and the lack of experimental activities. Based on the results of previous research, it also proves that the learning process, the use of innovative technology, and learning strategies are very influential on improving PSS and LE (Osborne et al., 2003; Çalik et al., 2014; Villafane et al., 2014). In addition to the factors of models, methods, strategies, and learning environment, the findings of previous studies reveal an interesting fact, namely that there is a relevance between PSS and LE based on gender and grade level. This condition is very relevant to the results of the research of Cheung (2007), as well as (Calik et al., 2014), showing that students' PSS and LE abilities have differences based on gender and grades. Studies from various countries such as those conducted by (Harvey \& Stables, 1986; Çalik et al., 2014) in Turkey, Cheung, (2011) in Hong Kong, Xu, (2013) in America, in England, and Zeidan and Jayosi, (2014) in Palestine, concluded that gender and grades levels affect students' PSS, self-efficacy (SE) and LE. Research that has been carried out in various countries has described the current condition of PSS and LE students, but it is still very limited in being studied in universities in Indonesia. Therefore, a research study to map the factual conditions of PSS and LE chemistry teacher candidates in Indonesia based on gender and grade level is very urgent to do. Thus, referring to the urgency of the research, the findings of this study are expected to be able to map the factual conditions of the PSS and LE chemistry teacher candidates simultaneously which have never been done so far. The purpose of this study was to determine the differences in problem-solving skills (PSS) and chemistry learning experiences (LE) of chemistry teacher candidates based on grade level and gender differences.

\section{Method}

The research design used a cross-sectional survey (Creswell, 2009; Iyankova et al., 2006) and interviews were conducted through focus group interviews (deep interview technique). Focus group interviews were carried out to collect qualitative data that could support quantitative data obtained based on a questionnaire (Ismail \& Jarrah, 2019). The advantage of the cross-sectional survey design method is that it is able to measure the relationship between two or more 
variables and interpret the situation of the research object (Stangor, 2004; Cohen et al., 2007). The research sample was taken from 3 universities and the total participants were 191 chemistry teacher candidates consisting of junior $(29.32 \%)$, sophomore $(32.46 \%)$, and freshman $(38.22 \%)$, and $31.94 \%$ male, and $68.06 \%$ female. (Table 1). At the survey and interview stage, 130 female and 61 male samples were determined based on the purposive random sampling technique (Fowler, 2002). The focus group interviews were conducted involving 12 lecturers and 40 students through deep interview techniques (Creswell, 2009).

Table 1: Description of sample characteristics

\begin{tabular}{llll}
\hline Male & Female & Grade Level & Total \\
\hline 23 & 50 & Freshman $\left(1^{\text {st }}\right.$ grade) & 73 \\
20 & 42 & Sophomore (2st grade) & 62 \\
18 & 38 & Junior (3t ${ }^{\text {st }}$ grade) & 56 \\
61 & 130 & Total & 191 \\
\hline
\end{tabular}

Based on the results of instrument validation, namely the construct validity and face validity, the Cronbach alpha coefficient value is obtained at $\alpha=.80>$ .70. so that the instrument is declared valid and reliable. Survey data were analyzed using the MANOVA test at the significance level of .05. and data from interviews were analyzed using the Patton technique (Creswell, 2009).

\section{Result and Discussion}

To find out the PSS and LE levels of pre-service chemistry teacher by gender and grades level differences are determined based on the standard deviation and average score as shown in table 2. Based on the data analysis, the LE level of chemistry teacher candidates occupies the highest position, then the PSS ability. The highest average score on learning experiences was found in female and junior grade of 88.552 (Table 2). For the PSS level, the chemistry teacher candidates showed that the female freshman grade was higher than the male PSS, both in freshman, sophomore, and junior grades.

Table 2: SD and Mean Scores PSS dan LE based on Gender and Grades Level

\begin{tabular}{lllll}
\hline & Gender & Grades & Mean & SD \\
\hline Problem & Male & 1st grade (Freshman) & 74.704 & 8.61 \\
Solving & & 2st grade (Sophomore) & 78.309 & 8.43 \\
Skills & & 3st grade (Junior) & 81.176 & 5.63 \\
& \multirow{2}{*}{ Female } & 1st grade (Freshman) & 78.989 & 8.02 \\
& & 2st grade (Sophomore) & 83.132 & 6.66 \\
& & 3st grade (Junior) & 85.957 & 7.85 \\
\hline
\end{tabular}

\begin{tabular}{lclll}
\hline & Gender & Grades & Mean & SD \\
\hline Learning & Male & 1st grade (Freshman) & 84.545 & 6.55 \\
Experie- & & 2st grade (Sophomore) & 85.739 & 3.88 \\
nces & & 3st grade (Junior) & 86.273 & 4.82 \\
& \multirow{2}{*}{ Female } & 1st grade (Freshman) & 85.498 & 5.80 \\
& & 2st grade (Sophomore) & 86.729 & 3.80 \\
& & 3st grade (Junior) & 88.552 & 7.09 \\
\hline
\end{tabular}

The results of the Manova test show that there are differences in PSS and LE based on grades with $p$ $<0.05$ (Table 3). Furthermore, gender has no difference with $p$ value $>0.05$ (the null hypothesis is accepted).

Table 3: Manova Test Results PSS and LE based on Gender and Grades Level

\begin{tabular}{lllll}
\hline Effect & & Value & F & Sig. \\
\hline Grades & Hotelling's Trace & .150 & 4.940 & .000 \\
& Roy's Largest & .854 & 5.048 & .000 \\
& Root & .170 & 5.156 & .000 \\
& Pillai's Trace & .156 & 9.29 & .000 \\
& Wilks' Lambda & & & \\
Gender & Hotelling's Trace & .011 & .590 & .600 \\
& Roy's Largest & .993 & .590 & .600 \\
& Root & .012 & .590 & .600 \\
& Pillai's Trace & .012 & .590 & .600 \\
& Wilks' Lambda t & & & \\
\hline
\end{tabular}

The data analysis then performed the Test of BSE (Between of Subjects Effects) test to test the differences of each factor against the dependent variable. The results showed that there was no difference between the PSS and LE of chemistry teacher candidates based on gender because the $\mathrm{p}$-value was obtained $>0.05$ (Table 4). However, for the grades level, there was a difference in LE for chemistry teacher candidates with a value of $p>0.05(p=.000)$.

Table 4: Test Results of Test of Between-Subjects Effects PSS and LE

\begin{tabular}{llll}
\hline Effect & Variabel Dependent & F & Sig. \\
\hline Gender & PSS & .590 & .204 \\
& Learning Experiencess & .590 & .204 \\
Grade & PSS & 5.036 & .000 \\
Levels & Learning Experiencess & 9.28 & .000 \\
\hline
\end{tabular}

The differences in PSS and LE between gender and grades were indicated by the results of the Tukey HSD Multiple Comparisons test. Based on the results of the Tukey HSD and Bonferroni tests, there were differences in PSS and LE between freshman, sophomore, and junior grades (Table 5) with a p-value $<0.05$. 
Table 5: Test Results of Multiple Comparisons PSS and LE

\begin{tabular}{|c|c|c|c|c|c|}
\hline Dependent Variable & & Grades & Grades & Mean & Sig. \\
\hline \multirow{6}{*}{$\begin{array}{l}\text { Problem Solving Skills } \\
\text { (PSS) }\end{array}$} & \multirow[t]{6}{*}{ Tukey HSD } & \multirow{2}{*}{ Freshman } & Sophomore & 5.7706 & .000 \\
\hline & & & Junior & 3.6934 & .004 \\
\hline & & \multirow[t]{2}{*}{ Sophomore } & Freshman & -5.7706 & .000 \\
\hline & & & Junior & 3.6934 & .000 \\
\hline & & \multirow[t]{2}{*}{ Junior } & Freshman & -4.6934 & .004 \\
\hline & & & Sophomore & 4.6934 & .000 \\
\hline \multirow{6}{*}{$\begin{array}{l}\text { Learning Experineces } \\
\text { (LE) }\end{array}$} & \multirow[t]{6}{*}{ Tukey HSD } & \multirow[t]{2}{*}{ Freshman } & Sophomore & -5.4071 & .000 \\
\hline & & & Junior & 5.6101 & .000 \\
\hline & & \multirow[t]{2}{*}{ Sophomore } & Freshman & 5.4071 & .004 \\
\hline & & & Junior & -4.7706 & .000 \\
\hline & & \multirow[t]{2}{*}{ Junior } & Freshman & -5.6101 & .000 \\
\hline & & & Sophomore & 4.7706 & .000 \\
\hline
\end{tabular}

The research findings reveal an interesting fact, in which the average PSS and LE ability of female students is higher than that of boys. The findings of this study are highly relevant to the research of Villafane et al., (2014) and Zeldin et al, (2008) showing that gender differences have an influence on student PSS and LE. In addition, student learning experiences (LE) greatly influence the development of positive attitudes towards chemistry learning, especially the application of inquiry-based learning (Wahyudiati et al., 2020; Mataka \& Kowalske, 2015). There is a tendency for women to have a higher PSS and LE because women have the more positive motivation, interest, selfconfidence, persistence in doing tasks, and chemical attitudes than men (Zeldin et al., 2008; Çalik et al., 2014; Villafane et al., 2014). The results of other studies also revealed the PSS and LE levels of chemistry teacher candidates based on grades. The research findings revealed that junior grades had the highest PSS and LE abilities than sophomore and freshman grades. These factual conditions indicate that the abilities of the PSS and LE of chemistry teacher candidates have increased along with the additional semesters taken. This condition is because in each semester students get additional learning experiences, both from face-to-face activities in class, as well as from practicum activities in the laboratory. The findings of this study are supported by various studies that reveal the development of problem-solving skills and student chemistry learning experiences that have developed quite significantly in the following semester (Sumardi et al., 2020; Wahyudiati, 2019; Zeidan \& Jayosi 2014). However, the weaknesses of the chemistry learning process are still centered on lecturers, the lack of new innovations, even the learning process only focuses on improving cognitive abilities (Zeidan \& Jayosi 2014; Ismiani et al., 2017; Dalgety et al., 2003).

The findings further prove that there are differences in PSS and LE based on grades, but there is no difference based on gender. The research findings are supported by the results of research by Bui and
Alfaro, (2011), Concannon and Barrow, (2012), and Dhindsa \& Chung, (2003) which reveal the fact that the abilities of PSS and LE chemistry teacher candidates do not have differences based on gender. There are differences in PSS and LE for chemistry teacher candidates based on grades levels due to the increase in learning experience gained in each (Dalgety et al., 2003). Previous studies have also proven that learning environments, practicum activities, the use of innovative technology, and learning strategies are very influential on improving science process skills and chemistry learning experiences (Çalik et al., 2014; Taber, 2011; Osborne, 2003). Furthermore, it was explained that the ability of PSS and LE has an impact on academic performance which can affect student efforts, persistence, and emotional reactions to the assignment so that it has an impact on improving learning outcomes and soft skills of prospective chemistry teachers (Wahyudiati et al., 2019; Mataka \& Kowalske, 2015; Zeidan \& Jayosi, 2014).

To strengthen the results of the previous findings, it is continued by measuring the PSS and LE abilities more specifically based on grade levels. The findings of the study showed that there were differences in the PSS and LE of chemistry teacher candidates between freshman and sophomore grades, freshman and junior grades, and sophomore and junior grades. The research findings are supported by previous research which revealed that grades level affects the PSS and LE of chemistry teacher candidates (Villafane et al., 2014; Osborne, 2003; Zeidan \& Jayosi, 2014), but is not influenced by gender (Çalik et al., 2014; Wahyudiati et al, 2020; Concannon \& Barrow, 2012). Thus, chemistry learning activities must be designed with learning activities that can support the development of soft skills of students for each semester level so that they are able to develop the attitude, psychomotor and cognitive aspects of prospective chemistry teachers as provisions for future career development. This condition is reinforced by various research results which reveal that PSS and LE greatly 
affect chemistry achievement at the college level (Ferrel \& Barbera, 2015; Myers \& Fouts, 1992; Dalgety et al., 2003; Fadli, 2019; Sutrisno et al., 2020; Uzuntiryaki \& Aydin, 2009; Zusho et al., 2003). Therefore, the ability of PSS and LE is an important factor to consider in chemistry education research from the tertiary, secondary, and primary levels. In addition, higher education institutions must facilitate lecturers to plan, implement, and evaluate chemistry learning programs that are collaborative and innovative -based so that they are expected to optimize the process and results of learning chemistry in higher education.

\section{Conclusion}

Based on the research results, it can be concluded that: 1) chemistry teacher candidates have a higher level of the chemistry learning experience (LE) than problem-solving skills (PSS); 2) the level of ability of female chemistry teacher candidates for PSS and LE was found to be higher than that of male chemistry teacher candidates; (3) there are differences in PSS and LE based on grades levels, but there is no difference between PSS and LE based on gender; 4) there is a difference between PSS and LE between junior, sophomore, and freshman. Therefore, it is recommended for lecturers and higher education to prioritize the development of PSS and LE (soft skills) in the chemistry learning process so as to improve the academic achievement of prospective chemistry teachers. As a follow-up, it is necessary to research how effective PSS and LE development strategies at the tertiary level are oriented towards 21st Century learning, and how to improve soft skills, affective, cognitive, and psychomotor abilities in lectures and chemistry laboratory courses which are still rarely investigated.

\section{References}

Bui, N.H., \& Alfaro, M.A. (2011), Statistics anxiety and science attitudes: age, gender and ethnicity factors, Coll. Student J., 45(3), 573-585.

Çalik, M., O"zsevgeç, T., Ebenezer, J., Artun, H., \& Ku"çu"k, Z. (2014). Effects of 'environmental chemistry' elective course via technology embedded scientific inquiry model on some variables. J. Sci. Educ. Techno., 23(3), 412-430.

Çalik, M., Ültay, N., Kolomuç, A., \& Aytar, A. (2014). A cross-age study of science student teachers' chemistry attitudes. Chem. Educ. Res. Pract., 16.

Cheung, D. (2007). Developing an instrument to measure students' attitudes toward chemistry lessons for use in curriculum evaluation. Paper presented at the 38th annual conference of the
Australasian Science Education Research Association, Fremantle, Australia.

Cheung, D. (2011). Evaluating student attitudes toward chemistry lessons to enhance teaching in the secondary school. Educ. quím, 22(2), 117-122.

Cohen, L., Manion, L., \& Morrison, K. (2007). Research methods in education. (6 $6^{\text {th }}$ Edition). London: Routledge.

Concannon, J. P., \& Barrow, L., H. (2012). A reanalysis of engineering majors' self-efficacy beliefs. Journal Sciience Education Technology, 21(6), 742-753.

Creswell, J. W. (2009). Research design: Qualitative, quantitative, and mixed methods approaches. Thousand Oaks, CA: Sage.

Dalgety, J., Coll, K.R., \& Jones, A. (2003). Development of chemistry attitudes and experiences questionnaire (caeq). Journal of Research in Science Teaching, 40 (7), 649-668.

Dhindsa, H. S. \& Chung, G. (2003). Attitudes and achievement of Bruneian science students. Internalational Journal of Science Education, 25, 907922.

Fadli, A, (2019). Problem solving skills and scientific attitudes of prospective teachers based on gender and grades level. International Journal of Scientific E Technology Research, 8(10). 3595-3599.

Fadli, A., \& Irwanto, I. (2020). The Effect of Local Wisdom-Based ELSII Learning Model on the Problem Solving and Communication Skills of Pre-Service Islamic Teachers. International Journal of Instruction, 13, 731-746.

Ferrel, B., \& Barbera, J. (2015). Analysis of students' self-efficacy, interest, and effort beliefs in general chemistry. Chem. Educ. Res. Pract, 16, 318-337.

Harvey, T. J., \& Stables, A. (1986). Gender differences in attitudes to science for third year pupils: An argument for single-sex teaching groups in mixed schools. Research in Science and Technological Education, 4(2), 163-170.

Irwanto, Rohaeti, E., \& Prodjosantoso, A. K. (2018b). Undergraduate students' science process skills in terms of some variables: A perspective from Indonesia. Journal of Baltic Science Education, 17(5), 751-772.

Ismail, S.A.A., \& Jarrah, A.M. (2019). Exploring preservice teachers' perceptions of their pedagogical preferences, teaching competence and motivation. International Journal of Instruction, 12(1), 493-510.

Ismiani, S., Syukri., \& Wahyudiati, D. (2017). Pengaruh penerapan metod problem-based learning terhadap sikap ilmiah dan hasil belajar biologi siswa kelas vii mts nw 01 kembang kerang. Biota, 10(1), 68-75. 
Iyankova, N. V., Creswell, J. W., \& Stick, S. L. (2006). Using mixed methods sequential explanatory design: From theory to practice. Field Methods, 18, 3-20.

Mataka, L. M., \& Kowalske, M. G. (2015). The influence of PBL on students' self-efficacy beliefs in chemistry. Chemistry Education Research and Practice, 16, 929-938.

Myers, R. E., \& Fouts, J. T. (1992). A cluster analysis of high school science classroom environments and attitude toward science. J. Res. Sci. Teach, 29, 929-937.

Nurlita, F. (2008). Penggunaan perangkat pembelajaran berdasarkan masalah untuk meningkatkan pemahaman konsep dan mengembangkan keterampilan berpikir kritis. Jurnal Ilmiah Pendidikan dan Pembelajaran, 4(2), 885-901.

Osborne, J., Simon, S., \& Collins, S. (2003). Attitudes towards science: A review of the literature and its implications. International Journal of Science Education, 25(9), 1049-1079.

Prabowo, S. A. (2015). The effectiveness of scientific based learning towards science process skill mastery of PGSD students. Indonesian Journal of Science Education, 4(1), 15-19.

Stangor, C., O. (2004). Research methods for behavioural sciences. Boston: Houghton Mifflin Co.

Sumardi, L., Rohman, A., \& Wahyudiati, D. (2020). Does the Teaching and Learning Process in Primary Schools Correspond to the Characteristics of the 21st Century Learning? International Journal of Instruction, 13(3), 357-370.

Sutrisno, H., Wahyudiati, D., \& Louise, I.S.Y. (2020). Ethnochemistry in the chemistry curriculum in higher education: exploring chemistry learning resources in sasak local wisdom. Universal Journal of Educational Research, 8(12A), 7833-7842.

Taber, K. S. (2011). Building the structural concepts of chemistry: Some considerations from educational research. Chemistry Education Research and Practice in Europe, 2(2), 123-158.

Uzuntiryaki, E., \& Aydin, Y. C. (2009). Development and validation of chemistry self-efficacy scale for college students. Res. Sci. Educ, 39(4), 539-551.

Villafane, S. M., Garcia, C. A., \& Lewis, J. E. (2014). Exploring diverse students' trends in chemistry self-efficacy throughout a semester of collegelevel preparatory chemistry. Chemistry Education Research and Practice, 15, 114-127.

Wahyudiati, D. (2010). Pengembangan perangkat pembelajaran berorientasi model pembelajaran diskusi pada pokok bahasan energi dan perubahannya untuk menumbuhkan sikap ilmiah siswa. Badan Penelitian dan Pengembangan.
Wahyudiati, D. (2016). Analisis efektivitas kegiatan praktikum sebagai upaya peningkatan hasil belajar mahaisswa. Jurnal Tastaif, 14(2), 143-168.

Wahyudiati, D. (2019). Self-Efficacy and Attitudes toward Chemistry of Pre-Service Chemistry Teachers: Gender and Grades Level Perspective. International Journal of Scientific \& Technology Research. 8(9), 1041-1044.

Wahyudiati, D., Rohaeti, E., Irwanto, Wiyarsi, A., \& Sumardi, L. (2020). Attitudes toward Chemistry, Self Efficacy, and Learning Experiences of PreService Chemistry Teachers: Grade Level and Gender Differences. International Journal of Instruction, 13(1), 235-254.

Wahyudiati, D., Sutrisno, H., \& Louise, I. S. Y. (2019). Investigation of attitudes towards chemistry and learning experiences of pre-srvice chemistry teachers. MIER Journal of Educational Studies Trends \& Practices, 9(2), 191-211,

Wiwit., Ginting, M. S., \& Firdaus, M. L. (2013). Penerapan pembelajaran kimia dasar menggunakan media power point 2010 dan phet simulation dengan pendekatan modification of reciprocal teaching berbasis konstruktivisme. Jurnal Exacta, 11(1), 29-32

Xu, X., Villafane, S. M., \& Lewis, J. E. (2013). College students' attitudes toward chemistry, conceptual knowledge and achievement: structural equation model analysis. Chemical Education Researcah and Practice, 14, 188-200.

Zeidan, H.A., \& Jayosi, R. M. (2014). Science process skills and attitudes toward science among palestinian secondary school students. World Journal of Education, 1(5), 13-24.

Zeldin, A. L., Britner, S. L., \& Pajares, F. (2008). A comparative study of the self-efficacy beliefs of successful men and women in mathematics, science, and technology careers. J. Res. Sci. Teach, 45(9), 1036-1058.

Zusho, A., Pintrich, P. R., \& Coppola, B. (2003). Skill and will: the role of motivation and cognition in the learning of college chemistry. Int. J. Sci. Educ, 25(9), 1081-1094 